\title{
Analisa Pergeseran Titik Pengamatan GPS pada Gunung Merapi Periode Januari-Juli 2015
}

\author{
Joko Purnomo, Ira Mutiara Anjasmara, dan Sulistiyani \\ Jurusan Teknik Geomatika, Fakultas Teknik Sipil dan Perencanaan, Institut Teknologi Sepuluh \\ Nopember (ITS) \\ Jl. Arief Rahman Hakim, Surabaya 60111 Indonesia \\ e-mail: ira@geodesy.its.ac.id, sulistiyani@esdm.go.id
}

\begin{abstract}
Abstrak - Gunung Merapi merupakan gunung api tipe A yaitu gunung api yang memiliki kegiatan magma dan erupsi tercatat sejak tahun 1600. Gunung Merapi merupakan salah satu gunung api teraktif di dunia. Hampir setiap periode Gunung Merapi mengalami erupsi. Periode ulang aktivitas erupsi berkisar antara 2 - 7 tahun. Untuk mengetahui kondisi gunung Merapi dilakukan beberapa metode pemantauan. Salah satu metode pemantauan Gunung Merapi yaitu dengan metode deformasi. Pemantauan deformasi yaitu pemantauan terhadap perubahan koordinat beberapa titik yang mewakili sebuah gunung api dari waktu ke waktu. Perhitungan deformasi pada penelitian ini dengan menggunakan data GPS CORS pengamatan Gunung Merapi pada stasiun KLAT, PLAW, DELS dan GRWH dengan titik ikat BPTK. Dari hasil pengolahan data GPS dengan GAMIT, didapat hasil nrms minimal adalah 0.231. nrms maksimal adalah 0.298 , dan rata-rata nrms adalah 0.249 . Sedangkan untuk pergeseran titik dari Januari hingga Juli 2015 memiliki nilai yang berbedabeda pada setiap titik. Pada bulan Januari dan Februari pola dan arah pergeseran semua titik sama namun besar pergeseran berbeda. Begitu pula pada bulan Mei dan Juni pola dan pergeseran sama namun besar pergeseran berbeda. Untuk bulan lainnya pergeseran memiliki arah yang berbeda dengan besar yang berbeda juga.
\end{abstract}

Kata kunci-Deformasi, GAMIT/GLOBK, GPS, Gunung Merapi, Pergeseran

\section{PENDAHULUAN}

G UNUNG Merapi merupakan salah satu gunung api aktif di dunia. Hampir setiap periode Gunung Merapi mengalami erupsi. Periode ulang aktivitas erupsi berkisar antara $2-7$ tahun. Aktivitas erupsi Gunung Merapi dengan ciri khas mengeluarkan lava pijar dan awan panas, tanpa membentuk kaldera (kawah) [1]. Hingga Juli 2015 Gunung Merapi masih mengalami aktivitas vulkanisme yang menunjukkan gunung tersebut masih aktif yaitu terjadi gempa vulkanik B pada 20 April, 2 Juni, 1 Juli dan 20 Juli. [2]

Gunung Merapi merupakan gunung api tipe A. Gunung aktif tipe A perlu dilakukan pemantauan aktivitasnya untuk prediksi letusannya apabila terjadi peningkatan aktivitas pada sewaktuwaktu. Sedangkan gunung api lainnya merupakan gunung api dengan tipe $\mathrm{B}$ dan $\mathrm{C}$. Gunung api tipe $\mathrm{B}$ dan $\mathrm{C}$ mengalami aktivitas sebagai manifestasi vulkanisme yang memiliki potensi kecil untuk meletus [3].

Untuk mengetahui kondisi gunung Merapi dilakukan beberapa metode pemantauan. Salah satu metode pemantauan gunung Merapi yaitu metode survei deformasi menggunakan data GPS CORS. Karakteristik deformasi yang dikaji meliputi posisi, arah, dan besar pergeseran. Dari nilai pergeseran yang didapat kemudian dilakukan analisa untuk mengetahui kondisi Gunung Merapi.

\section{METODOLOGI PENELITIAN}

\section{A. Lokasi Penelitian}

Lokasi penelitian adalah di Gunung Merapi, Yogyakarta. Gunung Merapi secara geografis lokasinya terletak pada koordinat $07^{\circ} 32^{\prime} 30^{\prime \prime}-07^{\circ} 52^{\prime} 30^{\prime \prime}$ LS dan 110¹5'00"'$110^{\circ} 37^{\prime} 30^{\prime \prime}$ BT.

\section{B. Peralatan dan Data}

Data yang diperlukan dalam penelitian ini adalah sebagai berikut.

1. Data

Data pengamatan yang digunakan adalah data pengamatan GPS pada stasiun PLAW, DELS, KLAT, GRWH. Sedangkan titik ikat yang digunakan yaitu data pengamatan GPS pada stasiun BPTK.

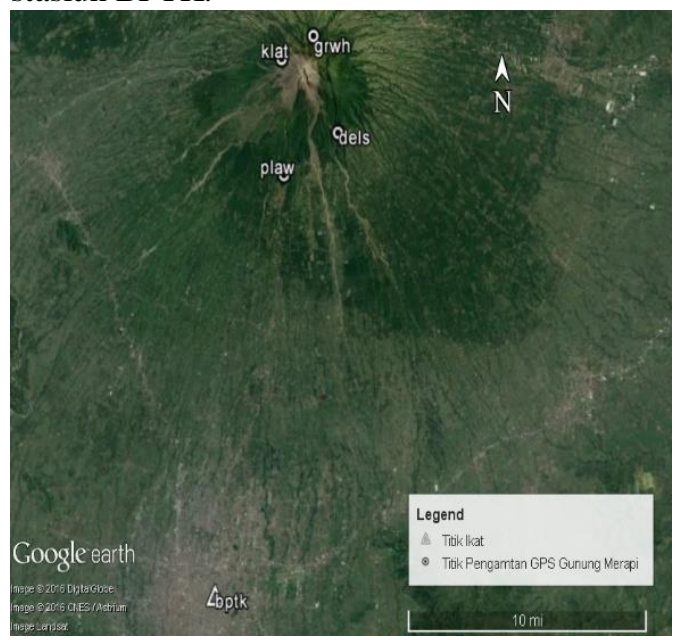

Gambar 1. Posisi Titik Pengamatan GPS Gunung Merapi

(Sumber : earth.google.com)

2. Tiga file data tambahan yaitu : file gelombang pasang surut, file atmosfer, file pemodelan cuaca.

3. Data orbit satelit; IGS SP3 ephemeris file (igsWWWD.sp3).

4. Nilai jam satelit; file navigasi RINEX (brdcDDD0.YYn).

5. Data Statistik Seismisitas Gunung Merapi Januari hingga Juli 2015.

Peralatan yang digunakan dalam penelitian ini meliputi:

1. Perangkat Keras (Hardware):

- Laptop

2. Perangkat Lunak (Software): 
- Sistem Operasi Linux Ubuntu 14.04 dan Windows 7

- Software Matlab

- Software GMT

- Software TEQC

- Software GAMIT/GLOBK

\section{Metode Penelitian}

Adapun tahap penelitian secara umum sebagai berikut:

1. Pengolahan GAMIT

Pengolahan GAMIT dilakukan dengan automatic batch processing perintah yang digunakan sebagai berikut.

$$
\text { sh_gamit -s YYYY DOYa DOYb -expt EXPT }
$$

Keterangan:

YYYY = tahun data yang diolah

DOYa $=$ DOY awal data yang diolah

$\mathrm{DOYb}=$ DOY akhir data yang diolah

$\mathrm{EXPT}=$ nama projek pengolahan

Analisis hasil pengolahan GAMIT dengan melihat postfit nrms pada $\mathrm{Q}$ file pada masing-masing DOY. Proses pengamatan GPS dapat dikatakan baik jika postfit nrms $\leq 0.3$ [4].

\section{Pengolahan GLOBK}

GLOBK adalah sebuah proses perhitungan Kalman Filtering yang bertujuan untuk mengkombinasikan solusi dari berbagai pengolahan data geodetik. Salah satu output pengolahan GLOBK adalah deret waktu koordinat GPS yang dikombinasi. Tujuan dari deret waktu ini menguji keber-ulangan koordinat (coordinate-repeatabilities) sehingga dapat digunakan untuk mengidentifikasi dan menghilangkan beberapa pengamatan atau stasiun yang diduga adalah outliers.

\section{Pergeseran}

Pergeseran adalah perpindahan dari posisi awal menuju posisi berikutnya [5]. Untuk mendapatkan nilai vektor pergeseran digunakan kurva linear dengan data hasil pengamatan. Fungsi kurva yang digunakan adalah fungsi linear, dengan formula sebagai berikut:

$y=a x+b$

Sedangkan rumus kecepatan vektor pergeseran

$$
X_{t}=X_{t o}+\left(t-t_{o}\right)
$$

Dalam hal ini,

$X_{t} \quad$ : koordinat stasiun pengamatan pada kala t

$X_{t o}$ : koordinat stasiun pengamatan pada kala $\mathrm{t}_{\mathrm{o}}$

$V \quad$ : pergeseran

Untuk menghitung besar parameter, digunakan prinsip kuadrat terkecil dengan formula matriks:

$$
X=\left(\mathrm{A}^{\mathrm{t}} \mathrm{P} \quad \mathrm{A}\right)^{-1}\left(\mathrm{~A}^{\mathrm{t}} \mathrm{P} \quad \mathrm{F}\right)
$$

Matriks A berisi data selang waktu pengamatan, matriks $F$ berisi perubahan posisi, dan matriks $\mathrm{x}$ adalah besar parameter yang dicari yaitu vektor pergeseran. Setelah menentukan besar parameter, nilai vektor pergeseran dapat ditentukan fungsinya dalam bentuk fungsi linear. Sehingga pada bidang datar akan didapatkan resultan pergeserannya VR melalui parameter Vn dan Ve, yakni pergeseran di sumbu northing dan easting:

$$
\mathrm{VR}=\sqrt{v e^{2}+v n^{2}}
$$

Sedangkan untuk menemukan arah vektor pergeserannya $(\alpha)$ dapat diketahui dengan menghitung parameter $\mathrm{Vn}$ dan $\mathrm{Ve}$ dengan rumus:

$$
\alpha=\tan V e / V n
$$

\section{HASIL DAN PEMBAHASAN}

Pada bagian ini akan ditampilkan hasil dari pelaksanaan penelitian yang telah dilakukan.

\section{A. Hasil Pengolahan Data}

Hasil pengolahan GAMIT perlu dilakukan evaluasi. Evaluasi hasil pengolahan data GPS dengan menggunakan GAMIT dilakukan untuk mengetahui kualitas pengolahan data. Proses evaluasi ini dilakukan dengan cara melihat nilai nrms hasil pengolahan harian. Nilai $n r m s$ solusi harian $\leq 0.3$ atau pada umumnya berada pada kisaran 0.2 menunjukkan solusi harian yang baik. [4]. Jika nilai nrms solusi harian diatas 0.3 mengindikasikan adanya masalah seperti cycle-slips yang tidak bisa dihilangkan, stasiun fixed dengan koordinat yang jelek, dll.

Nilai nrms dari hasil pengolahan data GPS dalam penelitian ini dapat dilihat pada Gambar 2.

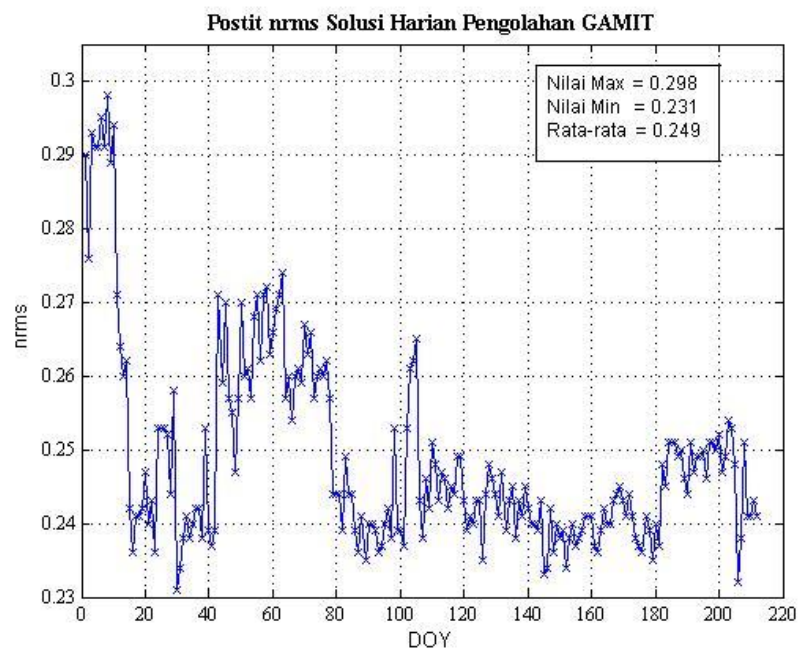

Gambar 2 Nilai nrms Solusi Harian Pengolahan GAMIT

Dari Gambar 2. dapat dilihat hasil nrms minimal adalah 0.231. nrms maksimal adalah 0.298, dan rata-rata nrms adalah 0.249. Hal ini menunjukkan bahwa pengolahan data sudah memberikan hasil yang sesuai dengan kriteria pengolahan data GPS menggunakan GAMIT.

\section{B. Analisa Pergeseran}

Berdasarkan hasil pengolahan data GPS kemudian dilakukan perhitungan pergeseran titik setiap bulannya.

1. Januari 2015

Besar Pergeseran bulan Januari ditunjukkan pada Tabel 1.

Tabel 1.

Pergeseran Januari 2015

\begin{tabular}{cccccc}
\hline \hline Stasiun & $\mathrm{dE}(\mathrm{mm})$ & $\mathrm{dN}(\mathrm{mm})$ & $\sigma \mathrm{E}(\mathrm{mm})$ & $\sigma \mathrm{N}(\mathrm{mm})$ & $R_{E N}$ \\
\hline DELS & -18.9 & -7.50 & 1.77 & 1.54 & 20.33 \\
GRWH & -2.95 & -8.88 & 0.84 & 0.99 & 9.36 \\
KLAT & 35.92 & 3.62 & 1.16 & 0.82 & 36.10 \\
PLAW & 8.5 & 3.4 & 0.88 & 0.72 & 9.15 \\
\hline \hline
\end{tabular}




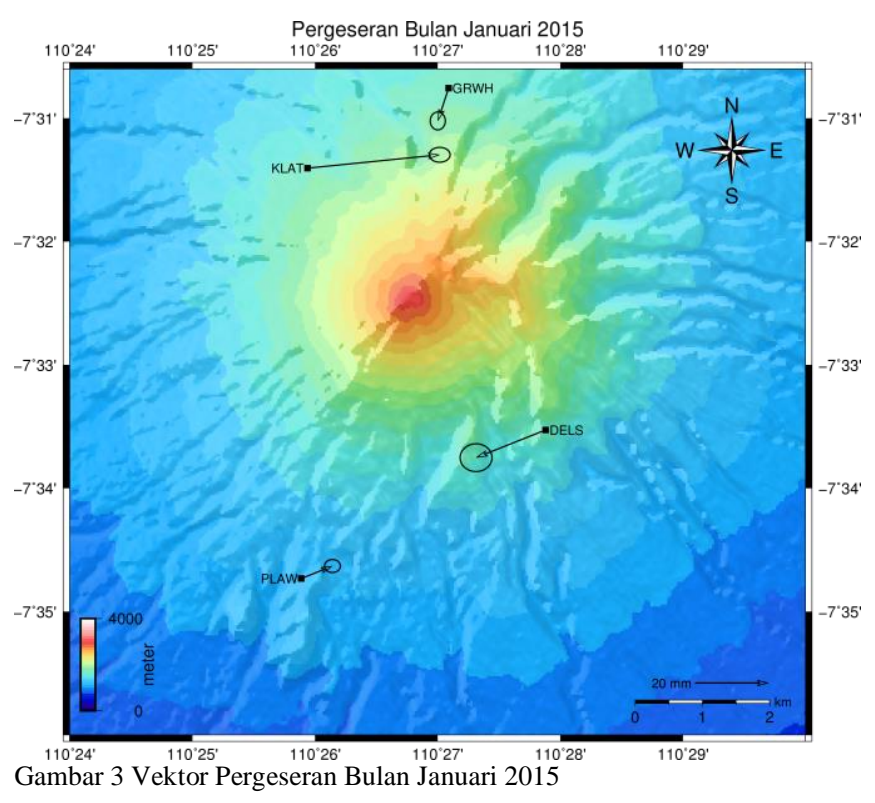

Berdasarkan Tabel 1. dan Gambar 3. pada bulan Januari titik KLAT bergeser ke arah timur $36.10 \mathrm{~mm}$. Titik GRWH mengarah ke puncak gunung Merapi yaitu pada arah selatanbarat sebesar $9.36 \mathrm{~mm}$. Titik DELS bergeser $20.33 \mathrm{ke}$ arah selatan-barat dan titik PLAW bergeser $9.15 \mathrm{~mm}$ ke arah utaratimur.

\section{Februari 2015}

Besar Pergeseran bulan Februari ditunjukkan pada Tabel 2.

Tabel 2.

Besar Pergeseran Februari 2015

\begin{tabular}{cccccc}
\hline \hline Stasiun & $\mathrm{dE}(\mathrm{mm})$ & $\mathrm{dN}(\mathrm{mm})$ & $\sigma \mathrm{E}(\mathrm{mm})$ & $\sigma \mathrm{N}(\mathrm{mm})$ & $R_{E N}$ \\
\hline DELS & -18.9 & -7.42 & 1.69 & 1.54 & 20.38 \\
GRWH & -2.37 & -8.07 & 0.72 & 0.99 & 8.41 \\
KLAT & 34.27 & 3.05 & 1.35 & 0.82 & 34.41 \\
PLAW & 7.79 & 2.67 & 0.82 & 0.72 & 8.23 \\
\hline \hline
\end{tabular}

Berdasarkan Tabel 2. dan Gambar 4. pada bulan Februari titik KLAT bergeser $34.41 \mathrm{~mm}$ ke arah timur. Titik GRWH mengarah ke puncak gunung Merapi yaitu pada arah selatanbarat sebesar $8.41 \mathrm{~mm}$. Titik DELS bergeser $20.37 \mathrm{~mm}$ ke arah selatan-barat dan titik PLAW bergeser $8.23 \mathrm{~mm}$ ke arah utaratimur. Arah dan pola pergeseran pada bulan Februari cenderung sama dengan pergeseran yang terjadi pada bulan Januari.

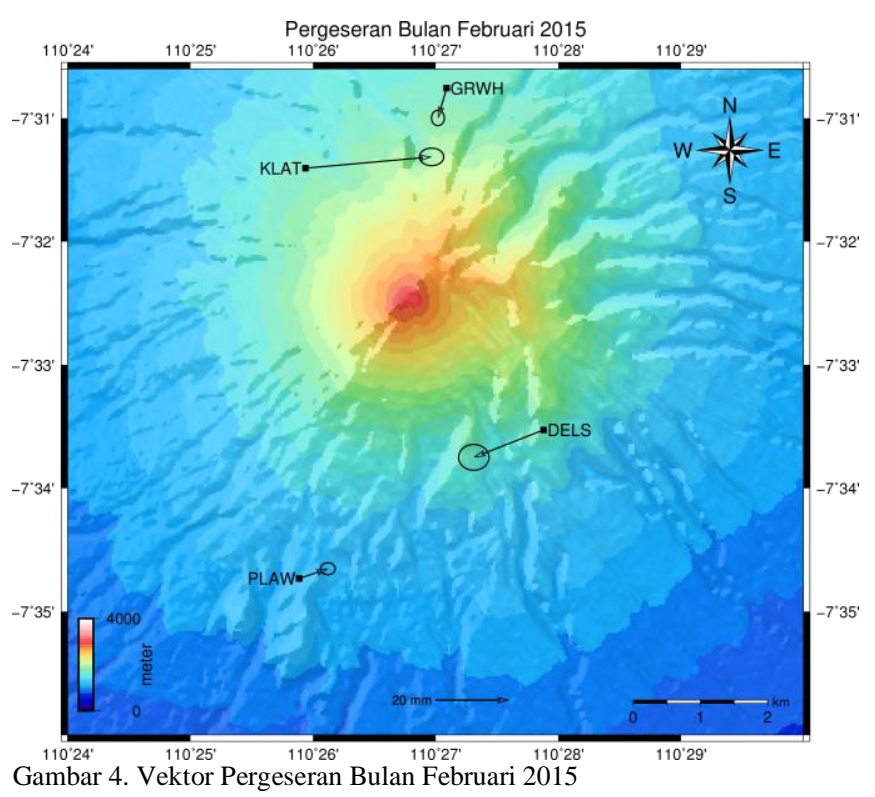

3. Maret 2015

Besar Pergeseran bulan Maret ditunjukkan pada Tabel 3.

Tabel 3.

Pergeseran Maret 2015

\begin{tabular}{cccccc}
\hline \hline Stasiun & $\mathrm{dE}(\mathrm{mm})$ & $\mathrm{dN}(\mathrm{mm})$ & $\sigma \mathrm{E}(\mathrm{mm})$ & $\sigma \mathrm{N}(\mathrm{mm})$ & $R_{E N}$ \\
\hline DELS & -3.49 & 4.74 & 1.59 & 1.35 & 5.89 \\
GRWH & -24.1 & -1.94 & 1.37 & 1.21 & 24.18 \\
KLAT & 10.2 & 0.25 & 0.96 & 0.9 & 10.20 \\
PLAW & -8.43 & -0.8 & 0.89 & 0.72 & 8.47 \\
\hline
\end{tabular}

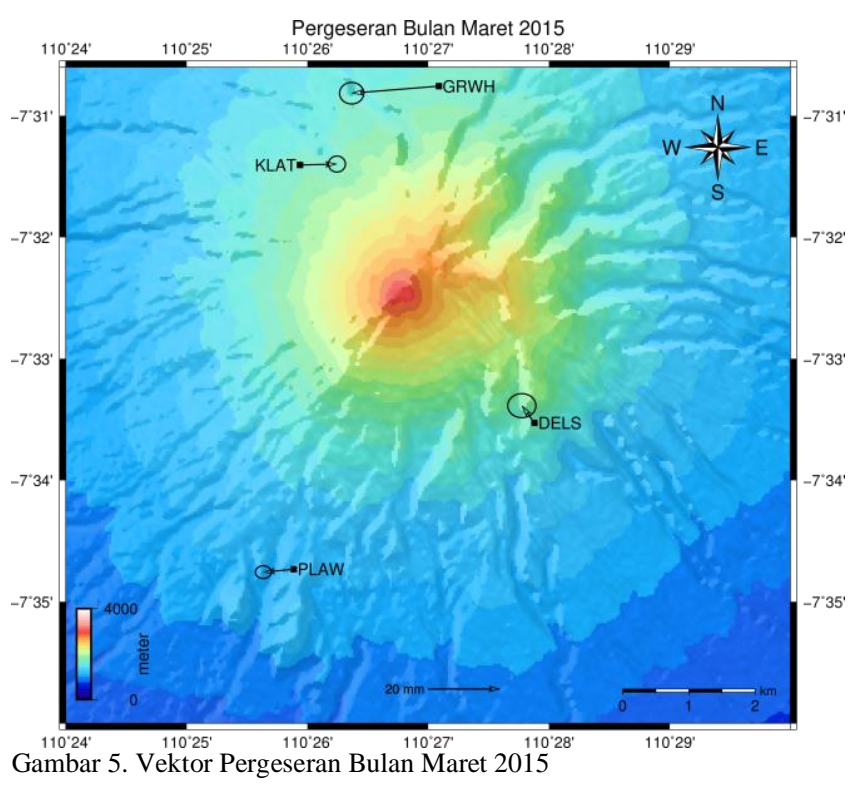

Berdasarkan Tabel 3. dan Gambar 5. pada bulan Maret 2015 titik DELS bergeser ke arah sebesar $5.88 \mathrm{~mm}$ puncak Gunung Merapi yaitu pada arah Barat-utara. Titik GRWH bergeser ke arah barat-selatan cenderung (ke arah barat) sebesar $24.18 \mathrm{~mm}$. Titik KLAT bergeser ke arah timur sebesar $10.20 \mathrm{~mm}$. Sedangkan titik PLAW bergeser ke arah barat sebesar $8.47 \mathrm{~mm}$. 4. April 2015

Besar Pergeseran bulan April ditunjukkan pada Tabel 4. 
Hasil Uji Statistik Pergeseran April 2015

\begin{tabular}{cccccc}
\hline \hline Stasiun & $\mathrm{dE}(\mathrm{mm})$ & $\mathrm{dN}(\mathrm{mm})$ & $\sigma \mathrm{E}(\mathrm{mm})$ & $\sigma \mathrm{N}(\mathrm{mm})$ & $R_{E N}$ \\
\hline DELS & -9.27 & 6.78 & 1.49 & 1.29 & 11.48 \\
GRWH & -3.02 & -2.97 & 1.07 & 1.18 & 4.24 \\
KLAT & 23.93 & 1.03 & 1.04 & 0.70 & 23.95 \\
PLAW & 6.48 & -5.43 & 0.82 & 0.67 & 8.45 \\
\hline \hline
\end{tabular}

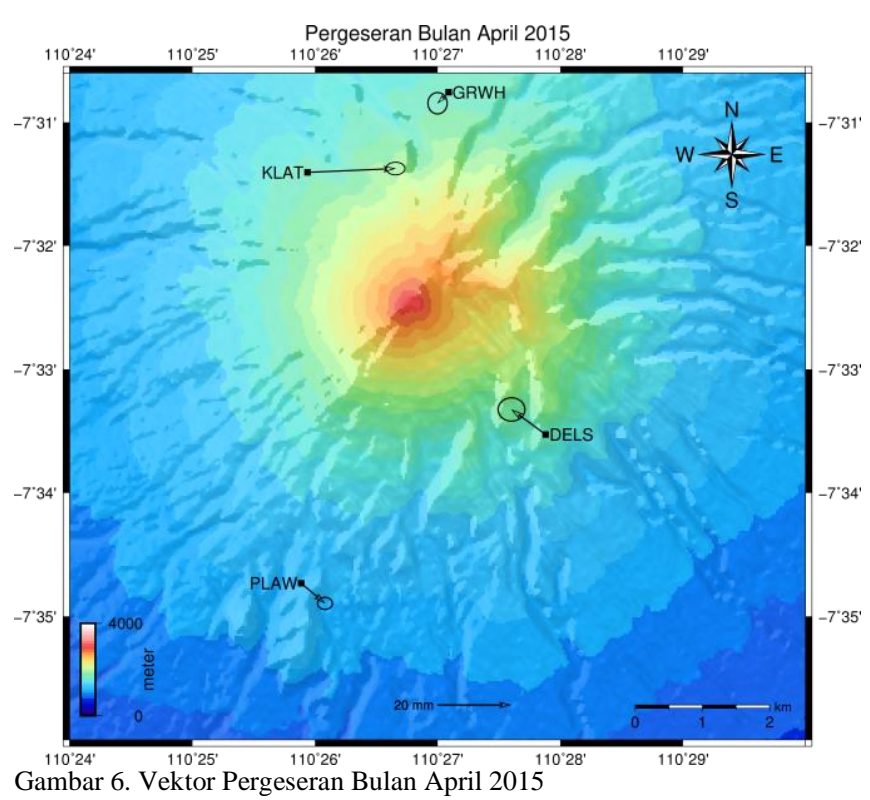

Berdasarkan Tabel 4 dan Gambar 6 pada bulan April 2015 titik DELS bergeser ke arah sebesar $11.48 \mathrm{~mm}$ puncak Gunung Merapi yaitu pada arah Barat-utara. Titik GRWH bergeser ke arah barat-selatan cenderung sebesar $4.24 \mathrm{~mm}$. Titik KLAT bergeser ke arah timur sebesar $23.9 \mathrm{~mm}$. Sedangkan titik PLAW bergeser ke arah barat-utara sebesar $8.45 \mathrm{~mm}$.

5. Mei 2015

Besar Pergeseran bulan Mei ditunjukkan pada Tabel 5.

Tabel 5 .

Pergeseran Mei 2015

\begin{tabular}{cccccc}
\hline \hline Stasiun & $\mathrm{dE}(\mathrm{mm})$ & $\mathrm{dN}(\mathrm{mm})$ & $\sigma \mathrm{E}(\mathrm{mm})$ & $\sigma \mathrm{N}(\mathrm{mm})$ & $R_{E N}$ \\
\hline GRWH & -31.20 & -9.00 & 1.66 & 1.44 & 32.48 \\
KLAT & 12.57 & 2.91 & 0.48 & 0.40 & 12.90 \\
PLAW & -8.52 & -3.32 & 0.71 & 0.52 & 9.14 \\
\hline \hline
\end{tabular}

Berdasarkan Tabel 5. dan Gambar 7. pada bulan Mei 2015 Data stasiun DELS tidak tersedia. Stasiun GRWH bergeser sebesar $32.48 \mathrm{~mm}$ ke arah selatan-barat. Sedangkan untuk KLAT bergeser ke arah timur sebesar $12.90 \mathrm{~mm}$. sedangkan titik PLAW bergeser ke arah selatan-barat sebesar $9.14 \mathrm{~mm}$.

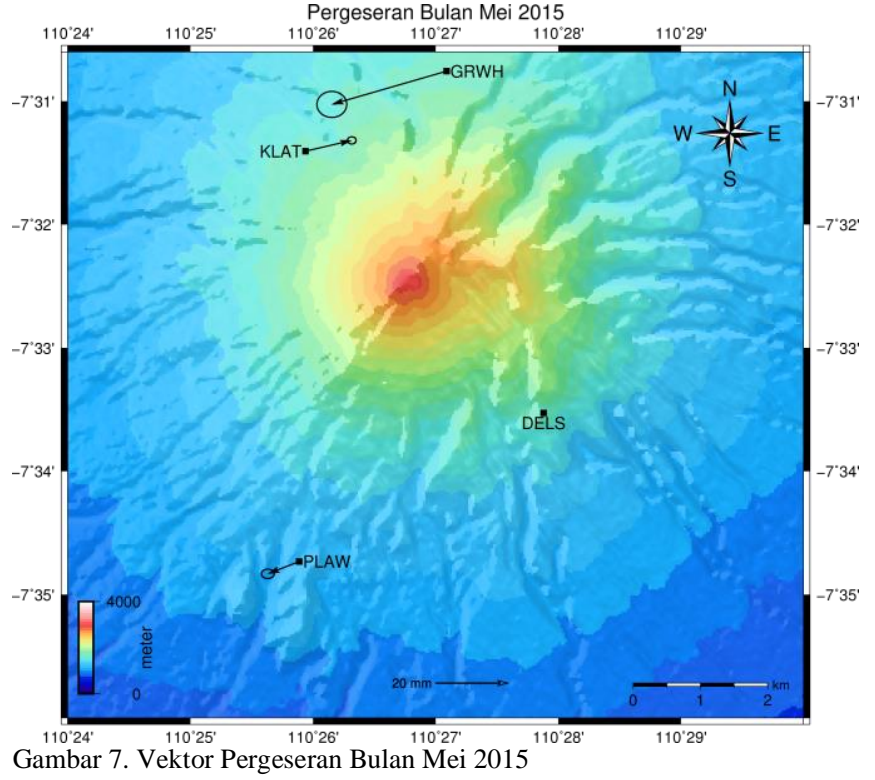

6. Juni 2015

Besar Pergeseran bulan Juni ditunjukkan pada Tabel 6.

Tabel 6.

Pergeseran Juni 2015

\begin{tabular}{cccccc}
\hline Stasiun & $\mathrm{dE}(\mathrm{mm})$ & $\mathrm{dN}(\mathrm{mm})$ & $\sigma \mathrm{E}(\mathrm{mm})$ & $\sigma \mathrm{N}(\mathrm{mm})$ & $R_{E N}$ \\
\hline DELS & -11.01 & 26.59 & 0.78 & 1.7 & 28.78 \\
GRWH & -36.02 & -11.49 & 1.40 & 1.32 & 37.81 \\
KLAT & 7.45 & 1.38 & 0.34 & 0.39 & 7.58 \\
PLAW & -16.98 & -2.78 & 0.75 & 0.58 & 17.21 \\
\hline \hline
\end{tabular}

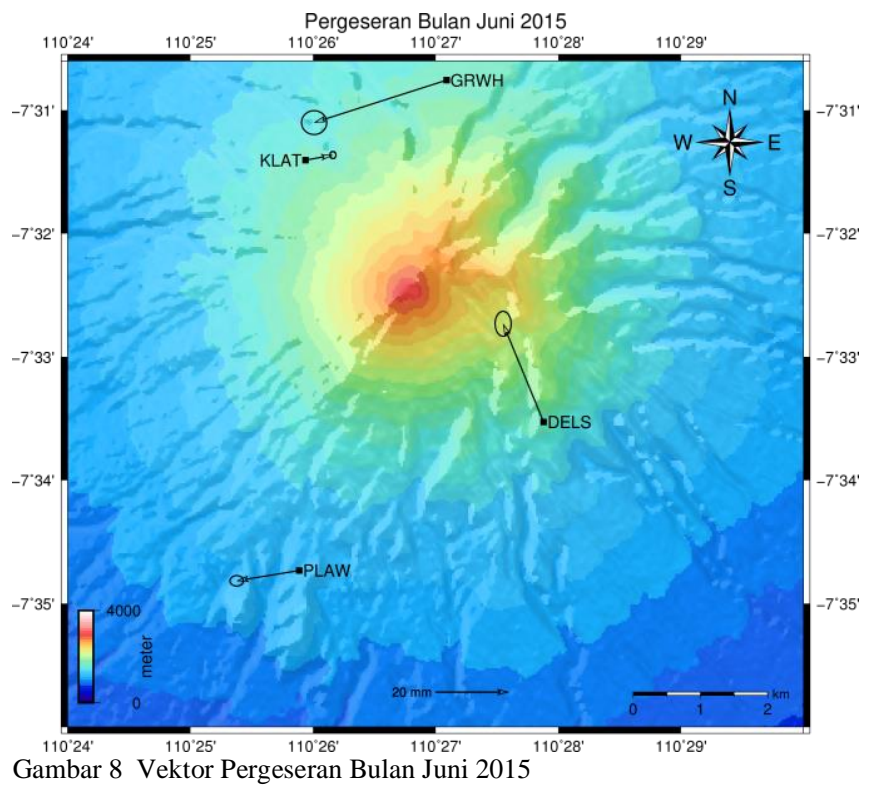

Berdasarkan Tabel 6 dan Gambar 8 pada bulan Juni 2015 DELS bergeser ke arah barat utara sebesar $28.78 \mathrm{~mm}$. Stasiun GRWH bergeser sebesar $37.81 \mathrm{~mm}$ ke arah selatan-barat. Titik KLAT bergeser ke arah timur sebesar $7.58 \mathrm{~mm}$. Sedangkan titik PLAW bergeser ke arah selatan-barat sebesar $17.21 \mathrm{~mm}$.

7. Juli 2015

Besar Pergeseran bulan Juli ditunjukkan pada Tabel 7. 
Pergeseran Juli 2015

\begin{tabular}{cccccc}
\hline \hline Stasiun & $\mathrm{dE}(\mathrm{mm})$ & $\mathrm{dN}(\mathrm{mm})$ & $\sigma \mathrm{E}(\mathrm{mm})$ & $\sigma \mathrm{N}(\mathrm{mm})$ & $R_{E N}$ \\
\hline DELS & -5.11 & 3.84 & 1.01 & 0.88 & 6.39 \\
GRWH & -0.66 & -11.71 & 0.72 & 0.77 & 11.73 \\
KLAT & 36.88 & 2.99 & 0.94 & 0.62 & 37.00 \\
PLAW & 8.03 & -3.91 & 2.08 & 1.59 & 8.93 \\
\hline \hline
\end{tabular}

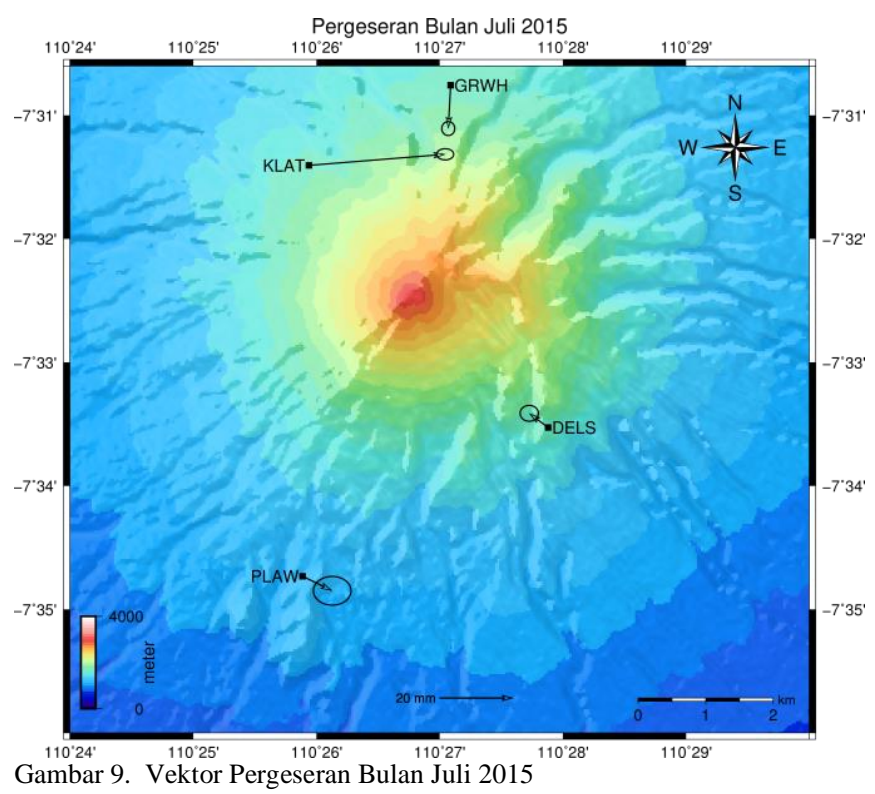

Berdasarkan Tabel 7 dan Gambar 9 Pada bulan Juli 2015 DELS bergeser ke arah barat utara sebesar $6.39 \mathrm{~mm}$. Stasiun GRWH bergeser sebesar $11.73 \mathrm{~mm}$ ke arah selatan. Titik KLAT bergeser ke arah timur sebesar $37.00 \mathrm{~mm}$. Sedangkan titik PLAW bergeser ke arah timur-selatan sebesar $8.93 \mathrm{~mm}$.

Setiap Bulan titik Pengamatan GPS pada Gunung Merapi mengalami pergeseran. Hal tersebut menunjukkan Gunung Merapi mengalami deformasi dan dapat dikategorikan aktif. Berdasarkan hasil perhitungan pergeserkan didapatkan resultan dari komponen Easting dan Northing seperti pada tabel 8.

Tabel 8.

Nilai Resultan Pergeseran

\begin{tabular}{ccccccccc}
\hline \hline \multirow{2}{*}{ Stasiun } & \multicolumn{7}{c}{ Pergeseran Bulan ke- .. 2015 (mm) } \\
\cline { 2 - 9 } & 1 & 2 & 3 & 4 & 5 & 6 & 7 & $\begin{array}{c}\text { Rata- } \\
\text { rata }\end{array}$ \\
\hline DELS & 20.33 & 20.37 & 5.88 & 11.48 & - & 28.78 & 6.39 & 15.54 \\
GRWH & 9.36 & 8.41 & 24.18 & 4.24 & 32.48 & 37.81 & 11.73 & 18.321 \\
KLAT & 36.10 & 34.41 & 10.20 & 23.95 & 12.90 & 7.58 & 37.00 & 23.16 \\
PLAW & 9.15 & 8.23 & 8.47 & 8.45 & 9.14 & 17.21 & 8.93 & 9.94 \\
\hline \hline
\end{tabular}

Berdasarkan Tabel 8, pergeseran terbesar untuk stasiun DELS terjadi pada bulan Juni sedangkan untuk pergeseran terkecil terjadi pada bulan Maret. Pergeseran terbesar pada Stasiun GRWH terjadi pada bulan Juni sedangkan untuk pergeseran terkecil terjadi pada bulan Februari. Stasiun KLAT, pergeseran terkecil terjadi pada bulan Juni sedangkan pergeseran terbesar terjadi pada bulan Juli. Stasiun PLAW, pergeseran terkecil terjadi bulan Februari dan pergeseran terbesar terjadi pada bulan Juni. Rata-rata pergeseran terbesar terjadi pada bulan Juni, kecuali KLAT. Hal ini diindikasikan terjadi karena adanya lonjakan jumlah seismisitas dari bulan Mei kebulan Juni seperti pada Gambar 10.

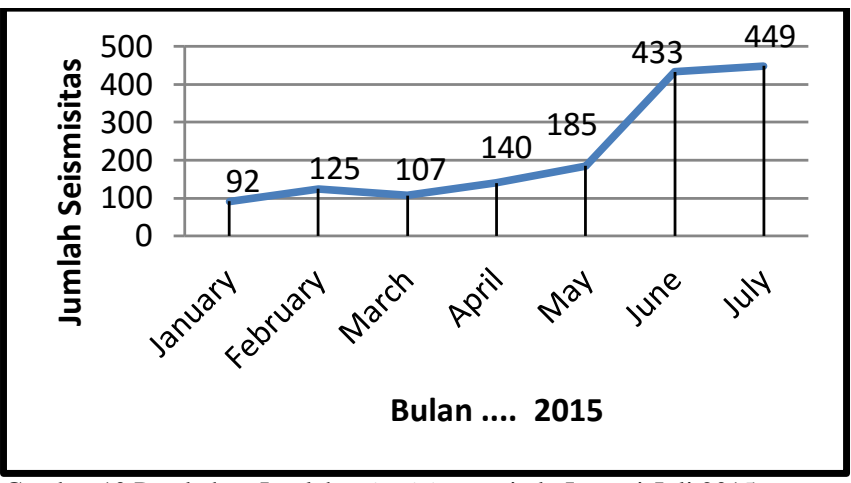

Gambar 10 Perubahan Jumlah seismisitas periode Januari-Juli 2015

Berdasarkan rata-rata pergeseran selama 7 bulan rata-rata pergeseran terbesar terjadi pada titik KLAT. Sedangkan ratarata pergeseran terkecil terjadi pada titik PLAW.

Jika dilihat dari vektor pegeseran Arah, pola pergeseran yang hampir seragam yang terjadi pada Januari-Februari, dan MeiJuni. Pada bulan-bulan tersebut dapat diasumsikan bahwa gaya endogen diduga berasal dari pengaruh gerakan sumber tekanan yang sama.

\section{KESIMPULAN}

Dari penelitian ini dapat diambil beberapa kesimpulan, yaitu: 1) Pergeseran titik pengamatan GPS selama Januari hingga Juli 2015 berada pada rentang berikut:

- DELS : $5.89 \mathrm{~mm}$ hingga $28.78 \mathrm{~mm}$ arah pergeseran pada Januari dan Februari menuju menuju ke arah selatan barat kemudian bulan Maret hingga Juli berubah arah menuju barat-utara menuju puncak Gunung.

- GRWH : $4.24 \mathrm{~mm}$ hingga $37.81 \mathrm{~mm}$ pada Januari dan Februari mengarah pada arah selatan-barat. Pada bulan Maret arah barat. Pada bulan April hingga Juni titik GRWH mengarah ke selatan-barat kembali. Kemudian berubah arah menuju selatan pada bulan Juli

- KLAT : $7.57 \mathrm{~mm}$ hingga $37.00 \mathrm{~mm}$ arah pergeseran menuju cenderung ke arah timur tetap selama 7 bulan.

- PLAW : $8.23 \mathrm{~mm}$ hingga $17.21 \mathrm{~mm}$ bergeser pada arah yang sama pada 2 bulan pertama yaitu Januari dan Februari kemudian bergeser ke arah yang berbeda-beda pada bulan berikutnya

2) Arah pegeseran pada bulan Januari dan Februari, Mei dan Juni memiliki arah dan pola yang sama. Sedangkan pada bulan Maret, April dan Juli cenderung berubah-ubah.

3) Rata-rata pergeseran selama 7 bulan rata-rata pergeseran terbesar terjadi pada titik KLAT. Sedangkan rata-rata pergeseran terkecil terjadi pada titik PLAW.

4) Pergeseran yang terjadi setiap bulan menunjukkan Gunung Merapi dalam keadaan aktif normal.

Saran yang dapat diberikan dari penelitian ini untuk ke depannya adalah sebagai berikut:

1. Melakukan penelitian analisa deformasi pada Gunung Merapi dengan menggunakan software pengolah data GPS yang berbeda untuk membandingkan hasil penelitian ini. 
2. Melakukan analisa vektor pergeseran dan regangan dengan menggunakan data harian pengamatan GPS (DOY) yang lebih lama selama 3 tahun

3. Perlu dilakukan pemodelan deformasi sehingga dapat diketahui lokasi sumber tekanan magma sehingga dapat diketahui penyebab perbedaan pola, arah dan besar pergeseran.

\section{DAFTAR PUSTAKA}

[1] Susilo, Ariadi N dan Rudiarto, Iwan. 2014. Analisis Tingkat Resiko Erupsi Gunung Merapi Terhadap Permukiman di Kecamatan Kemalang, Kabupaten Klaten. Jurnal Teknik PWK Volume 3 Nomor 12014.

[2] BPPTKG. 2015. Data seismisitas Gunung Merapi Periode Januari-Juli 2015.

[3] VSI. 2008. Pengenalan Gunung Api. Badan Geologi. Bandung: ESDM

[4] King, R., Herring, T.A, \& McClusky, S.C. 2015. GAMIT Reference Manual, Release 10.6. Department of Earth, Atmospheric, and Palnetary Sciences, Massachusetts Institute of Technology.

[5] Saputra, R., Awaluddin, M., \& Janu, F. 2015. Perhitungan Velocity Rate Cors Gnss Di Wilayah Pantai Utara. Jurnal Geodesi UNDIP 